\title{
Review
}

\section{The promise of human rights: Constitutional government, democratic legitimacy, and international law}

\author{
Jamie Mayerfeld \\ University of Pennsylvania Press, Philadelphia, 2016, \\ ISBN: 9780812248166
}

Contemporary Political Theory (2018) 17, S30-S34. https://doi.org/10.1057/s41296017-0101-7; published online 7 March 2017

Human rights aspire to cross-border validity, recognition, and enforcement. Nation state sovereignty is the capacity to determine laws within national borders regardless of other states' and organizations' preferences and viewpoints. So insofar as human rights actually obtain, to that extent nation states are less sovereign. Put more sharply: if nation states are truly sovereign, human rights are not possible. This Catch-22 bedevils the project for advancing human rights. It is why human rights are much more likely to be advanced within a polity than through any kind of international political or legal arrangement. The "promise of human rights" lies not in overcoming the Catch-22 but in coping with it. In clear prose and with thoughtful arguments, Jamie Mayerfeld attempts to square a circle that cannot be squared. He would connect constitutional government with international law such that both somehow retain their integrity in a mutual relationship that, by definition, can only erode each. Why erode? Because to be devoted to the idea of universally valid human rights is to champion not universally valid norms but the universal embrace of culturally particular norms. For example, either individual rights generally trump group rights or vice versa. Human rights have been constructed in both ways. I am with Mayerfeld in my preference for constructing human rights as fundamentally individual rights. But what I regard as a particular cultural preference, he views as a necessary truth: "Insisting on universal human rights is not about imposing some people's values on others. It is about preventing the imposition of some people's values on others" (p. 29). And if, for purposes of justice, one particular conception of human rights were preferable to another, some imposition would seem unavoidable.

Consider one of Mayerfeld's main examples. He discusses the Bush Administration's official policy on torture, defined as the "intentional infliction of severe physical or mental point or suffering" (p. 122). From a human rights perspective,

(C) 2017 Macmillan Publishers Ltd. 1470-8914 Contemporary Political Theory Vol. 17, S1, S30-S34 www.palgrave.com/journals 
the fact that international law "places an absolute legal prohibition on torture" (p. 125 ) is crucial. For Mayerfeld, this fact itself establishes a binding obligation on all nations to abjure torture: "Today the prohibition against torture is widely recognized as a jus cogens norm that cannot be overridden even by treaty or international custom" (p. 126). Jus cogens refers to supposedly imprescriptible norms of international law. In this context, Mayerfeld persuasively criticizes "American exceptionalism," the United States' policy of self-exemption from international human rights legal norms. Self-exemption proceeds, for example, by rendering "international human rights commitments nonjusticiable" or unenforceable in American courts (p. 146). It enabled the Bush Administration's "legal rationalization of torture" (p. 114), for example in the "August 1, 2002, Department of Justice memo stipulating the interrogation techniques do not constitute torture unless they inflict pain as severe as that which accompanies crippling injury, organ failure, or death" (p. 123). Mayerfeld simply "take[s] it for granted that torture is wrong ... torture is wrong even when it "works"' (p. 124). But human rights advocates need to make an argument as to why torture is wrong. And torturers will not be persuaded by the claim that torture is simply wrong or that international instruments prohibit it.

Further, one wonders how exactly international custom or law might effectively bind political communities (especially communities that do not regard themselves as so bound, such as the United States). On what basis are they so bound? According to which interpreters, who speak with what authority? Only members of the European Union have persuasive answers to these questions as long as the questions are about the EU (Mayerfeld's single positive example). The effort to end torture is not advanced by international instruments that obtain only at the pleasure of particular political communities. It is advanced by the free adoption of the corresponding human rights norms into these communities' domestic legal, social, and political orders. Communities that freely accept norms are more likely than other communities to actually practice them.

To be sure, Mayerfeld advances excellent arguments in favor of grounding human rights domestically. He argues for (liberal democratic) constitutional government in a mutually reinforcing relationship with international law. How he does so is at the core of his book. It has three elements: the European Union as a successful example of uniting the domestic order with international human rights instruments; the United States as a candidate for such a unity (both despite the fact that, and because, the American government during the Bush administration practiced torture and the current president promises to revive it); and a "Madisonian" formula to achieve that unity.

The first core element establishes an internal connection between domestic and international norms. Mayerfeld's conviction that a "commitment to preventing human rights violations by one's own government makes the involvement of international institutions necessary" (p. 73), and that the "adoption of international

(c) 2017 Macmillan Publishers Ltd. 1470-8914 Contemporary Political Theory Vol. 17, S1, S30-S34 S31 
human rights law is partly a matter of its incorporation into domestic law" (p. 13), leads to his most intriguing proposal: a "Madisonian system of transnational human rights protections" (p. 15). Mayerfeld wisely emphasizes the primacy of the nation state in this interrelationship (wisely because the venue of human rights enforcement is overwhelming within the nation state and because a nation state that embraces human rights will be more effective than any international instrument or institution in guaranteeing them). The "idea is not to displace responsibility upward, but rather to reaffirm one's responsibility (as a state) by increasing the number of other entities that are simultaneously responsible for fulfilling a shared commitment to human rights" (p. 76).

Madison was, of course, the architect of a specifically democratic form of government. Mayerfeld's concern is with the very different issue of advancing human rights in non-democratic polities. While he asserts that "transnational problems require democratic decision making at the transnational level" (p. 73), his main focus is on democratic nation states. He wants to "help democracies fulfill their own constitutional commitments" in the specific sense that international human rights instruments and institutions "complete the domestic constitutional order" (p. 73). He addresses head-on the well-known objection that international human rights law is necessarily undemocratic and counters with a punch to the right and one to the left: first, while "democracy requires popular government," the purpose of democracy is not to "realize the people's will" but to "secure justice" (p. 4); second, justice through democracy "requires, and is not in tension with, international human rights law" (p. 4).

In this context, too, Mayerfeld well deploys what he calls a "Madisonian conception of democracy," the idea of taming political power through checks and balances - but now displaced from an internal organizing principle of domestic order to the interrelationship he advocates between domestic orders and human rights institutions and instruments. Mayerfeld's is a conception of lofty moral obligation - a "promise among citizens and officials to hold one another accountable in a shared project of crafting and enacting policies that promote justice" (p. 4) - operationalizable through down-to-earth checks and balances ("where citizens and officials monitor each other to prevent the misuse and abuse of political power" (p. 4)).

The second core element concerns the European Union and its strengths. The EU exemplifies Mayerfeld's vision of a multilateral Madisonian constitutionalism that alone can effectively protect human rights. Because "European countries have become co-guardians of human rights within each national jurisdiction" (p. 6), respect for human rights is stronger there than anywhere else in the world. I see three problems here. First, as a self-monitoring confederation of most liberal democratic welfare states, many of them wealthy, all of them sharing various elements of Western culture, the EU is unique and cannot be analogized to any other part of the world. It has no purchase in North or South America, in the Middle 
East, in Africa, or in Asia, precisely areas in which the need for human rights is far more urgent than in the EU. Second, while Mayerfeld is correct that the "European human rights regime is not confined to regional mechanisms" and that most EU members "have ratified and given strong support to global treaties" (p. 93), the effectiveness of human rights project in Europe surely is due to the European states themselves. Precisely the identity between the EU and its constituent states distinguishes the EU from all other international organizations. Third, recent events across the EU cast doubt on Mayerfeld's untroubled optimism. He asserts that the "language of human rights" is now so "deeply internalized in Europe's national and international institutions," and that "public perceptions of the boundaries between acceptable and unacceptable government behavior" are so deeply formed, that "a return to authoritarianism is unthinkable" in most European countries (p. 91). How can anyone be so sure?

The third core element concerns the USA and its weaknesses. Mayerfeld urges non-European communities, and the United States in particular, to learn from the EU. Because in the U.S. "domestic human rights protections... are both fragile and incomplete" (p. 4) - indeed, the "U.S. legal system has permitted widespread and systematic human rights abuses, and in fact genuine atrocities" (p. 185) international human rights law "offers much-needed reinforcement" and "does not undermine but rather shores up the constitution" (p. 4). Mayerfeld is quite right to assert that "Human rights require multiple, overlapping protections," including mutual oversight in the form of checks and balances (p. 184). His counsel is wise that the "United States, its individual rights tradition notwithstanding, can benefit from the incorporation of international human rights law" (p. 184). He is spot-on when he recognizes that any viable form of cosmopolitanism "does not imply the disappearance of the nation-state," in part because "some cosmopolitan goals may prove unattainable without the preservation of the nation-state" (p. 67).

Less persuasive is his interpretation of the United States Constitution as itself mandating the human rights idea. For example, the due process clauses of the Fifth and Fourteenth Amendments guarantee the individual's right to be charged only in accord with the law, a right to a fair trial, and a right to legal defense. They do not guarantee that the legal process will necessarily uphold human rights values. And Mayerfeld's claim that "to a large extent international human rights law recapitulates promises found in the U.S. Constitution" (p.184) ignores the fact that rights of humans are quite distinct from rights of citizens in logic and substance. Further, the United States is generally unconstrained by international law. Any particular administration has the power to commit human rights violations in the name of national self-interest (consider Bush fils then, Trump now). Mayerfeld is surely right that "Effective criminalization is the indispensable backbone of the anti-torture regime" (p. 129). But the American government will not criminalize its own international policy. Absent the kind of international third force Mayerfeld imagines, perceived national self-interest determines that policy.

(c) 2017 Macmillan Publishers Ltd. 1470-8914 Contemporary Political Theory Vol. 17, S1, S30-S34 S33 
Despite these reservations, The Promise of Human Rights constitutes a splendid contribution to the literature. And the notion of a Madisonian, checks-andbalances-compact between liberal democratic polities, on the one hand, and international human rights law and institutions, on the other, deserves book-length treatment of its own.

Benjamin Gregg

University of Texas, Austin, TX 78712, USA

bgregg@austin.utexas.edu 